\title{
Neto 1 Is an Auxiliary Subunit of Native Synaptic Kainate Receptors
}

\author{
Man Tang, ${ }^{1,3 \star}$ Kenneth A. Pelkey, ${ }^{5 \star}$ David Ng, ${ }^{1,3 \star}$ Evgueni Ivakine, ${ }^{1}$ Chris J. McBain, ${ }^{5}$ Michael W. Salter, ${ }^{2,4}$ \\ and Roderick R. McInnes ${ }^{1,3,6}$ \\ Programs in ${ }^{1}$ Developmental and Stem Cell Biology and ${ }^{2}$ Neurosciences and Mental Health, The Research Institute, Hospital for Sick Children, Toronto, \\ Ontario M5G 1X8, Canada, Departments of ${ }^{3}$ Molecular Genetics and ${ }^{4}$ Physiology, University of Toronto, Toronto, Ontario M5S 1A8, Canada, ${ }^{5}$ Program in \\ Developmental Neurobiology, Eunice Kennedy Shriver National Institute of Child Health and Human Development, National Institutes of Health, Bethesda, \\ Maryland 20892, and 'Lady Davis Research Institute, Jewish General Hospital, McGill University, Montreal, Quebec H3T 1E2, Canada
}

Ionotropic glutamate receptors of AMPA, NMDA, and kainate receptor (KAR) subtypes mediate fast excitatory synaptic transmission in the vertebrate CNS. Auxiliary proteins have been identified for AMPA and NMDA receptor complexes, but little is known about KAR complex proteins. We previously identified the CUB (complement C1r/C1s, Uegf, Bmpl) domain protein, Neto1, as an NMDA receptorassociated polypeptide. Here, we show that Netol is also an auxiliary subunit for endogenous synaptic KARs. We found that Netol and KARs coimmunoprecipitated from brain lysates, from postsynaptic densities (PSDs) and, in a manner dependent on Netol CUB domains, when coexpressed in heterologous cells. In Neto1-null mice, there was an $\sim 50 \%$ reduction in the abundance of GluK2-KARs in hippocampal PSDs. Neto 1 strongly localized to CA3 stratum lucidum, and loss of Neto1 resulted in a selective deficit in KAR-mediated neurotransmission at mossy fiber-CA3 pyramidal cell (MF-CA3) synapses: KAR-mediated EPSCs in Neto1-null mice were reduced in amplitude and decayed more rapidly than did those in wild-type mice. In contrast, the loss of Neto2, which also localizes to stratum lucidum and interacts with KARs, had no effect on KAR synaptic abundance or MF-CA3 transmission. Indeed, MF-CA3 KAR deficits in Neto1/Neto2-doublenull mutant mice were indistinguishable from Netol single-null mice. Thus, our findings establish Neto1 as an auxiliary protein required for synaptic function of KARs. The ability of Netol to regulate both NMDARs and KARs reveals a unique dual role in controlling synaptic transmission by serving as an auxiliary protein for these two classes of ionotropic glutamate receptors in a synapse-specific fashion.

\section{Introduction}

Pharmacological, biophysical, and molecular studies indicate three principal classes of ionotropic glutamate receptors: AMPARs, NMDARs, and kainate receptors (KARs). AMPARs mediate the majority of rapid glutamatergic transmission, while NMDARs are recruited with increased neuronal activity through relief of voltage-dependent $\mathrm{Mg}^{2+}$ blockade, allowing them to serve as coincidence detectors to gate synaptic plasticity induction (Traynelis et al., 2010). The roles of KARs in synaptic transmission are less well understood and largely de-

Received Dec. 18, 2010; revised May 24, 2011; accepted May 25, 2011.

Author contributions: M.T. and K.A.P. designed research; M.T. and K.A.P. performed research; M.T. and D.N. contributed unpublished reagents/analytic tools; M.T., K.A.P., E.I., C.J.M., and M.W.S. analyzed data; M.T., K.A.P., C.J.M., M.W.S., and R.R.M. wrote the paper.

This study was supported by Grants MOP-7315 and IOP-54037 from the Canadian Institutes of Health Research to R.R.M., and an NICHD Intramural award to C.J.M.; R.R.M. and M.W.S. hold Canada Research Chairs; M.W.S. is an International Research Scholar of the Howard Hughes Medical Institute. The funders had no role in study design, data collection and analysis, decision to publish, or preparation of the manuscript. We thank L. Ploder, R. Szilard, D. Mahuran, and R. Reithmeier for technical advice; and K. Roche for the FLAG-GluK2 plasmid construct.

${ }^{*}$ M.T., K.A.P., and D.N. contributed equally to this work.

The authors declare no competing financial interests.

Correspondence should be addressed to either of the following: Roderick R. McInnes, Lady Davis Research Institute, Jewish General Hospital, McGill University, Montreal, QC H3T 1E2, Canada, E-mail: rod.mcinnes@mcgill.ca; or Michael W. Salter, Program in Neurosciences and Mental Health, The Research Institute, Hospital for Sick Children, Toronto, 0N M5G 1X8, Canada, E-mail: mike.salter@utoronto.ca.

DOI:10.1523/JNEUROSCI.6617-10.2011

Copyright $\odot 2011$ the authors $\quad 0270-6474 / 11 / 3110009-10 \$ 15.00 / 0$ pend on their subcellular localization. In presynaptic terminals, KARs modulate neurotransmitter release to regulate presynaptic forms of plasticity (Contractor et al., 2000, 2001; Kamiya and Ozawa, 2000; Schmitz et al., 2001). At postsynaptic sites, KARs yield synaptic currents of small amplitude with slow decay kinetics (Castillo et al., 1997; Vignes and Collingridge, 1997) and have also been found to act as metabotropic receptors that regulate neuronal excitability (Melyan et al., 2002; Fisahn et al., 2005; Ruiz et al., 2005). KARs are tetrameric ion channels formed by the combination of five subunits: the low-affinity GluK1, GluK2, and GluK3 subunits (Egebjerg et al., 1991; Sommer et al., 1992; Schiffer et al., 1997); and the high-affinity subunits GluK4 and GluK5 (Werner et al., 1991; Herb et al., 1992). In the hippocampus, KARmediated EPSCs have been characterized at both mossy fiberCA3 pyramidal cell (MF-CA3) (Castillo et al., 1997; Vignes and Collingridge, 1997; Mulle et al., 1998) and Schaffer collateral inputs onto CA1 interneurons (Cossart et al., 1998; Frerking et al., 1998; Bureau et al., 1999). At MF-CA3 synapses, postsynaptic KARs composed of GluK2/GluK5 and GluK2/GluK4 heteromers (Petralia et al., 1994; Contractor et al., 2003; Darstein et al., 2003; Ruiz et al., 2005; Fernandes et al., 2009) mediate a small slow component of the EPSC (Castillo et al., 1997; Vignes and Collingridge, 1997). The long decay time constants observed for KAR-EPSCs at these synapses are similar to those described for heteromeric GluK2/GluK5 KARs but differ from the faster decay 
kinetics of recombinant GluK2 homomeric KARs (Barberis et al., 2008), thus highlighting the contribution of different subunits to the biophysical properties of KARs.

A number of proteins have been shown to associate with KARs (Mehta et al., 2001; Coussen et al., 2002; Hirbec et al., 2003; Coussen et al., 2005; Laezza et al., 2007), some of which have been implicated in regulating receptor kinetics (Bowie et al., 2003; Garcia et al., 1998; Zhang et al., 2009). Indeed, the CUB domaincontaining protein Neto 2 has recently been found to prolong the decay kinetics and increase the glutamate-evoked currents of recombinant GluK2 homomeric KARs in heterologous cells (Zhang et al., 2009). Neto1, a close homolog of Neto2, has also been shown to enhance glutamate-evoked currents of GluK2 homomeric KARs, though to a much lesser extent than does Neto2 (Zhang et al., 2009). In the brain, Neto2 can interact with KARs (Zhang et al., 2009), but the roles of either Neto1 or Neto2 in regulating the function of native, synaptic KARs, many of which are the GluK2/GluK5 heteromeric subtype (Petralia et al., 1994), are still unknown. Here, we report that Neto1, like Neto2, also associates with synaptic KARs. Moreover, loss of Neto1, but not of Neto2, greatly reduces the abundance of hippocampal postsynaptic KARs, leading to diminished MF-CA3 KAR-mediated EPSCs with altered kinetics. Together, our results establish Netol as a KARassociated protein that critically regulates both postsynaptic density (PSD) abundance and channel properties of native KARs.

\section{Materials and Methods}

Mice. Mice of four different genotypes (wild-type, Neto1-null, Neto2null, and Neto1/Neto2-null) were used in this study and were maintained in the Toronto Center for Phenogenomics. Generation of Neto1-null mice was described previously (Ng et al., 2009). To generate Neto2-null mice, exons 3 through 6 from Neto 2 were deleted by homologous recombination, thus creating an in-frame stop mutation (see Fig. 2). Mouse R1 embryonic stem (ES) cells were electroporated, and positive clones were identified by Southern blotting, expanded, and injected into C57BL/6J blastocysts to generate chimeric mice. Transmitting male chimeras were crossed with $\mathrm{C} 57 \mathrm{BL} / 6 \mathrm{~J}$ female mice to identify germline-transmitting chimeras. Heterozygous pups were then intercrossed to obtain wild-type, heterozygous, and homozygous mutant mice in a mixed genetic background. Neto1/Neto2-null mice were generated by intercrossing Neto1null and Neto2-null mice.

Antibodies. Rabbit antibodies to Neto2 were raised by injecting rabbits with a GST-Neto2 fusion protein encoding the last 75 aa of Neto2. Affinity-purified antibodies were isolated from antisera by using MBPNeto2 fusion protein coupled to activated $\mathrm{CNBr}$-Sepharose columns. The generation of guinea pig anti-Netol antibodies has been described previously (Chow et al., 2004). The following commercial antibodies were used: rabbit polyclonal antibodies to GluK2 (Abcam), GluK5, GluA2/3 (Millipore), GluN2B (Novus Biologicals), and actin (Abcam); mouse monoclonal antibodies to GluN1 (BD Biosciences), VAMP2 (Synaptic Systems), NeuN (Millipore), and hemagglutinin (HA) (Covance); and goat polyclonal antibodies to Neto2 (R\&D Systems).

Mammalian expression constructs. Full-length Netol cDNA (encoding amino acids 1-533), full-length Neto2 cDNA (encoding amino acids 1-525), and deletion mutants Neto1- $\Delta$ CUB1-HA, Neto1- $\Delta$ CUB2-HA, Neto1- $\Delta$ CUB1 + 2-HA, Neto1- $\Delta$ cyto-HA, Neto2- $\Delta$ CUB1-HA, Neto2$\Delta$ CUB2-HA, Neto2- $\Delta$ LDLa-HA, and Neto2- $\Delta$ cyto-HA were generated by PCR and subcloned into a variant of pcDNA3.1mycHisA(+) (Invitrogen) containing two copies of the influenza HA epitope tag, and sequence verified. FLAG-GluK2 was a kind gift from Dr. Katherine Roche (National Institutes of Health).

Cell culture and transfection. For coimmunoprecipitation experiments, HEK293 cells were transfected with FuGene HD (Roche) at $70 \%$ confluency. Forty-eight hours after transfection, cells were washed once with ice-cold $1 \times$ PBS and lysed in RIPA buffer [50 mM Tris/HCl, pH 7.4, 150 mм NaCl, 1 mм EDTA, 1\% Nonidet P-40, 0.1\%
SDS, $0.5 \%$ deoxycholate (DOC), and protease inhibitors]. Lysed cells were incubated on ice for $30 \mathrm{~min}$ and were centrifuged at 13,000 $\times g$ for $15 \mathrm{~min}$ at $4^{\circ} \mathrm{C}$.

Coimmunoprecipitation. Cell lysates $(\sim 1.0 \mathrm{mg}$ of protein) were incubated with antibodies for $2 \mathrm{~h}$ at $4^{\circ} \mathrm{C}$ on a rotating platform. Lysates were subsequently incubated with $20 \mu \mathrm{l}$ GammaBind IgG beads (GE Healthcare) for $1 \mathrm{~h}$ at $4^{\circ} \mathrm{C}$ on a rotating platform. After incubation, beads were washed twice with RIPA buffer, twice with RIPA buffer minus SDS and DOC, and once with TBS-T (100 mM Tris/HCl, pH 7.5, $150 \mathrm{~mm} \mathrm{NaCl}$, $0.1 \%$ Tween-20). Bound proteins were eluted with SDS sample buffer and subjected to SDS-PAGE and immunoblotting. For immunoprecipitation from crude synaptosomal fractions, prepared as previously described (Gingrich et al., 2004), $1 \mathrm{mg}$ of synaptosomal protein was incubated with antibodies or normal rabbit IgGs overnight with rotation at $4^{\circ} \mathrm{C}$, and subsequently incubated with $30 \mu \mathrm{l}$ of GammaBind IgG beads for $2 \mathrm{~h}$ with rotation at $4^{\circ} \mathrm{C}$. Beads were washed twice with RIPA buffer, twice with RIPA minus SDS and DOC, and once with TBS-T. Bound proteins were eluted with SDS sample buffer, and subjected to SDSPAGE and immunoblotting.

Crude synaptosomes and PSD isolation. Crude synaptosomes were prepared as previously described (Gingrich et al., 2004) from wildtype, Neto1-null, or Neto2-null mouse brains. The PSD fraction was prepared from pooled hippocampi as described previously (Cho et al., 1992), except that PSDs were extracted only once with $1 \%$ Triton $\mathrm{X}-100$.

Immunohistochemistry. Immunostaining was adapted from Schneider Gasser et al. (2006). Briefly, fresh $250 \mu \mathrm{m}$ vibratome-cut hippocampal slices, trimmed from sagittal brain slices, were fixed in $2 \%$ PFA/PBS on ice for $10 \mathrm{~min}$, washed three times in PBS, and incubated "free floating" in blocking solution (10\% goat serum, $0.1 \%$ Triton-X in PBS) for $1 \mathrm{~h}$ at room temperature. Primary antibodies in blocking solution were incubated with slices for $24 \mathrm{~h}$ under gentle agitation at $4^{\circ} \mathrm{C}$. Slices were washed three times in PBS, and incubated with appropriate secondary antibodies for $24 \mathrm{~h}$ under gentle agitation at $4^{\circ} \mathrm{C}$. Following incubation, slices were washed three times with PBS, transferred, and mounted on to glass slides with Immuno-Mount (Thermo Scientific). Images were acquired using a Zeiss LSM 510 confocal microscope.

Hippocampal slice preparation. Slices were prepared as previously described (Pelkey et al., 2005) using P15-P22 wild-type, Neto1-null, Neto2-null, or Neto1/Neto2-null mice, as indicated. Briefly, animals were anesthetized with isoflurane and decapitated, allowing removal of the brain into ice-cold saline solution $\left(130 \mathrm{~mm} \mathrm{NaCl}, 24 \mathrm{~mm} \mathrm{NaHCO}_{3}\right.$, $3.5 \mathrm{~mm} \mathrm{KCl}, 1.25 \mathrm{~mm} \mathrm{NaH}_{2} \mathrm{PO}_{4}, 0.5 \mathrm{~mm} \mathrm{CaCl}, 4.5 \mathrm{~mm} \mathrm{MgCl}_{2}$, and 10 mu glucose, saturated with $95 \% \mathrm{O}_{2}$ and $5 \% \mathrm{CO}_{2}, \mathrm{pH} 7.4$ ). After dissection of the brain, individual hemispheres were transferred to the stage of a VT-1000S vibratome (Leica Microsystems) and sectioned to yield transverse hippocampal slices $(300 \mu \mathrm{m})$, which were incubated in the above solution at $35^{\circ} \mathrm{C}$ for at least a $30 \mathrm{~min}$ recovery period until use. All animal procedures conformed to the National Institutes of Health animal welfare guidelines.

Whole-cell recordings. All recordings were interleaved with the experimenter blind to mouse genotype. Individual slices were transferred to a recording chamber and perfused $(2-3 \mathrm{ml} / \mathrm{min})$ with extracellular solution ( $130 \mathrm{~mm} \mathrm{NaCl}, 24 \mathrm{~mm} \mathrm{NaHCO}_{3}, 3.5 \mathrm{~mm} \mathrm{KCl}, 1.25 \mathrm{~mm} \mathrm{NaH}_{2} \mathrm{PO}_{4}, 2.5$ $\mathrm{mm} \mathrm{CaCl}_{2}, 1.5 \mathrm{~mm} \mathrm{MgCl}_{2}, 10 \mathrm{~mm}$ glucose, $0.005-0.010 \mathrm{~mm}$ bicuculline methiodide saturated with $95 \% \mathrm{O}_{2}$ and $5 \% \mathrm{CO}_{2}, \mathrm{pH} 7.4,32-35^{\circ} \mathrm{C}$ ). Whole-cell patch-clamp recordings using a multiclamp 700A amplifier (Molecular Devices) in voltage-clamp mode [holding potential $\left(\mathrm{V}_{\mathrm{h}}\right)=$ -70 or $+40 \mathrm{mV}$, as indicated] were made from individual CA3 pyramidal neurons, and were visually identified with infrared video microscopy and differential interference contrast optics. Recording electrodes (4-5 $\mathrm{M} \Omega$ ) pulled from borosilicate glass (World Precision Instruments) were filled with intracellular solution composed of the following: $95 \mathrm{~mm} \mathrm{Cs}-$ gluconate, $5 \mathrm{~mm} \mathrm{CsCl}, 0.6 \mathrm{~mm}$ EGTA, $5 \mathrm{~mm} \mathrm{MgCl}_{2}, 4 \mathrm{~mm} \mathrm{NaCl}, 2 \mathrm{~mm}$ $\mathrm{Na}_{2}$ ATP, 0.3 mм NaGTP, 40 mм HEPES, 10 mм BAPTA, 1 mм QX-314, $\mathrm{pH}$ 7.2-7.3, and 290-300 mOsm. Uncompensated series resistance $(8-15 \mathrm{M} \Omega)$ was rigorously monitored by the delivery of small voltage steps at regular intervals, and recordings were discontinued following changes of $>10 \%$. Synaptic responses (paired pulses or trains of four 
A

Crude synaptosomes

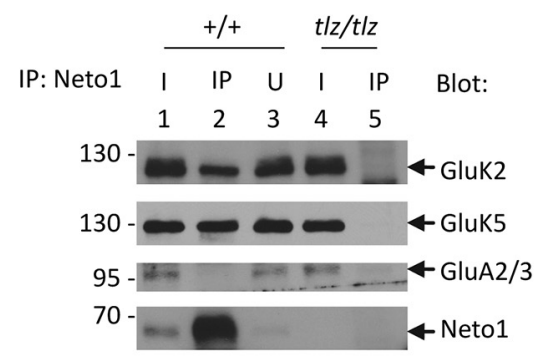

C

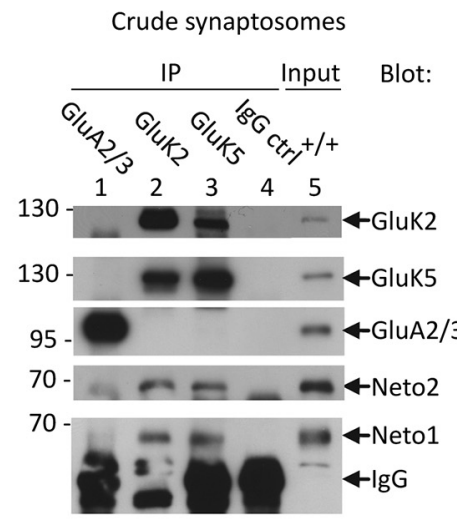

$\mathbf{E}$

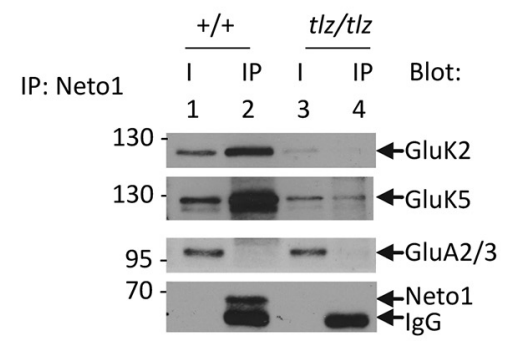

B

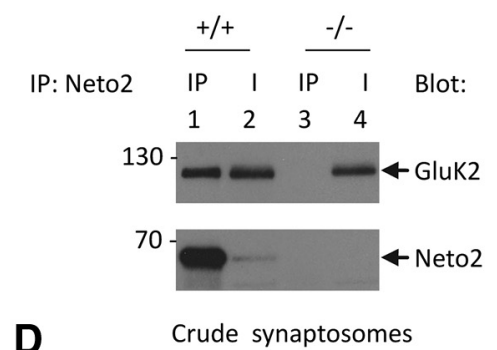

D.

IP: Neto1

$+/+\quad t / z / t / z$

Blot:

130
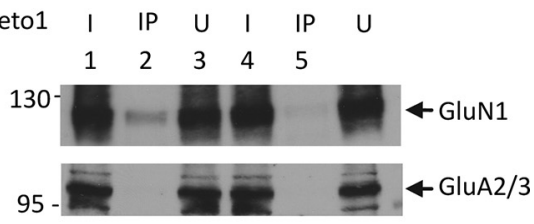

$70-$

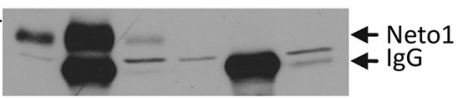

$\mathbf{F}$

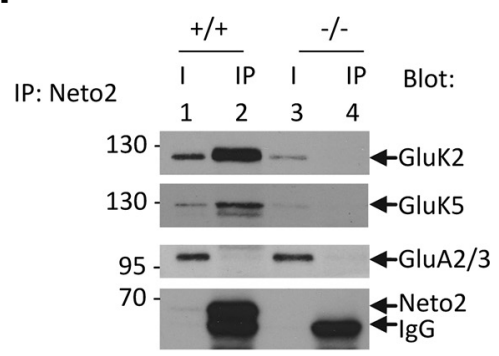

G

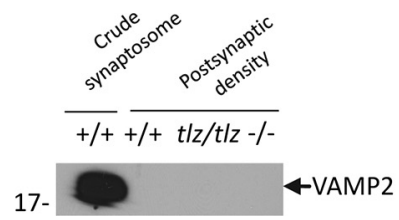

Figure 1. Neto1 and Neto2 associate with KARs in vivo. $\boldsymbol{A}-\boldsymbol{D}$, Immunoblots of immunoprecipitates from adult wild-type $(+/+)$ and Net01-null ( Neto $1^{\text {tz }}$ (t) $^{\text {tr }}$ or Neto2-null (Neto2 ${ }^{-1-}$ ) crude synaptosomes. Both the input and the unbound fraction for the immunoblot were $2 \%$ of the volume of the sample used in the immunoprecipitation experiment. $\boldsymbol{E}, \boldsymbol{F}$, Net01 and Neto 2 are part of PSD KAR protein complexes. Immunoblot of immunoprecipitates from adult wild-type $(+/+)$ and Net01-null (Neto $7^{\text {tz/ttz }}$ ) or Net02-null (Neto2 ${ }^{-1-}$ ) PSD. The input for the immunoblot analysis is $1 \%$ of the volume of sample used in the immunoprecipitation experiment. $G$, The purity of PSD preparations of wild type $\left(+/+\right.$ ), Neto1-null (Neto $7^{\text {tz/t/z }}$ ), and Neto2-null (Neto2 ${ }^{-1-}$ ) mice was tested by immunoblotting for the presynaptic protein VAMP-2. Blot, Antibody used for immunoblot analysis; I, input, IP, immunoprecipitate; U, unbound fraction, to show that the Neto1 antibody can efficiently immunoprecipitate Neto 1 protein from the synaptosomal samples.

pulses, both at $20 \mathrm{~Hz}$ ) were evoked at $0.1 \mathrm{~Hz}$ (for train recordings) or 0.2 $\mathrm{Hz}$ (for paired-pulse recordings) by low-intensity microstimulation (100 $\mu$ s duration; $10-30 \mu \mathrm{A}$ intensity) via a constant-current isolation unit (A360, World Precision Instruments) connected to a patch electrode filled with oxygenated extracellular solution in either the dentate gyrus or stratum lucidum for MF inputs, or in the stratum radiatum for associational/commissural (A/C) inputs. The mossy fiber origin of EPSCs was confirmed by a rapidly rising AMPA receptor-mediated component showing strong short-term frequency facilitation and in train protocols by a residual KAR-mediated component upon AMPA receptor antagonism at a $\mathrm{V}_{\mathrm{h}}$ of $-70 \mathrm{mV}$. For $\mathrm{MF}$ train recordings, initially dualcomponent KA/AMPAR-mediated synaptic responses were monitored at $\mathrm{V}_{\mathrm{h}}=-70 \mathrm{mV}$, following which the KAR-mediated component was pharmacologically isolated by applying the AMPA receptor-specific antagonist 1-(4-aminophenyl)-3-methylcarbamyl-4-methyl-3,4-dihydro7,8-methylenedioxy-5H-2,3-benzodiazepine (GYKI 53655) (50 $\mu \mathrm{M}$, Tocris Bioscience). The GYKI-resistant component at $\mathrm{V}_{\mathrm{h}}=-70 \mathrm{mV}$ was con- firmed to be KAR-mediated by subsequent application of DNQX (25 $\mu \mathrm{m}$, Tocris Bioscience) in the continued presence of GYKI 53655 and the holding potential was moved to $+40 \mathrm{mV}$ to obtain the NMDA receptor-mediated component of EPSCs followed by application of the NMDA receptor antagonist DL-APV $(100 \mu \mathrm{M}$, Tocris Bioscience) in the continued presence of GYKI 53655 and DNQX. For paired-pulse experiments examining just AMPA and NMDA components at MF or A/C inputs, EPSCs were first obtained and monitored at $\mathrm{V}_{\mathrm{h}}=-70 \mathrm{mV}$, then the NMDA component was monitored at $\mathrm{V}_{\mathrm{h}}=+40 \mathrm{mV}$ in the presence of DNQX and confirmed by subsequent application of DL-APV.

Data analysis. To measure AMPAR- and KAR-mediated EPSCs, averaged traces (10-20 individual sweeps) obtained in GYKI 53655 with DNQX at $\mathrm{V}_{\mathrm{h}}=-70 \mathrm{mV}$ were digitally subtracted from averaged traces obtained at the end of the control and GYKI 53655-alone conditions, respectively. Similarly, for NMDARmediated EPSC analysis, averaged traces obtained in DL-APV at $\mathrm{V}_{\mathrm{h}}=+40 \mathrm{mV}$ were digitally subtracted from those obtained in GYKI 53655/DNQX at $\mathrm{V}_{\mathrm{h}}=+40 \mathrm{mV}$. For each recording, EPSC amplitudes were measured during a 1-2 ms window around the peak of the waveform of the averaged traces for each condition. KAR-mediated and NMDARmediated EPSC amplitudes were measured for the fourth pulse of the trains and normalized to the amplitude of the corresponding AMPARmediated EPSC to eliminate slice-to-slice and animal-to-animal variability in the number of fibers recruited by extracellular stimulation. Short-term frequency facilitation was assessed using the AMPAR or NMDAR-mediated EPSCs by determining the ratio of the amplitude of the fourth to the first EPSC in the train (P4/ $\mathrm{P1}$ ). In paired-pulse recordings examining just AMPA and NMDA components of MF and $\mathrm{A} / \mathrm{C}$ inputs, the amplitudes of the first EPSCs were used to characterize NMDA/AMPA ratios, and paired-pulse ratios were determined by the ratios of the amplitudes of the second peak to the first peak (P2/P1). Data are presented as means \pm SEMs, unless otherwise indicated. Statistical significance was assessed using parametric (paired or unpaired $t$ tests) or nonparametric (Mann-Whitney $U$ test) tests, as appropriate.

\section{Results}

Neto1 and Neto 2 interact with native KARs in the postsynaptic density

Both Neto1 and Neto2 have been shown to enhance glutamateevoked currents of recombinant GluK2 homomeric KARs in heterologous cells (Zhang et al., 2009). Neto2 was also found to be a KAR-interacting protein in cerebellar lysates (Zhang et al., 2009). Given the sequence and structural similarity between Netol and Neto2, we asked whether Neto1 might also associate with KARs in vivo. Using whole-brain synaptosomal preparations, we found that anti-Neto1 antibodies coimmunoprecipitated the GluN1 subunit of the NMDARs (Fig. $1 D$ ) as we reported previously $(\mathrm{Ng}$ et al., 2009). We also demonstrated that anti-Netol antibodies coimmunoprecipitated the GluK2 and GluK5 subunits of KARs 


\section{A Neto2 gene targeting strategy}

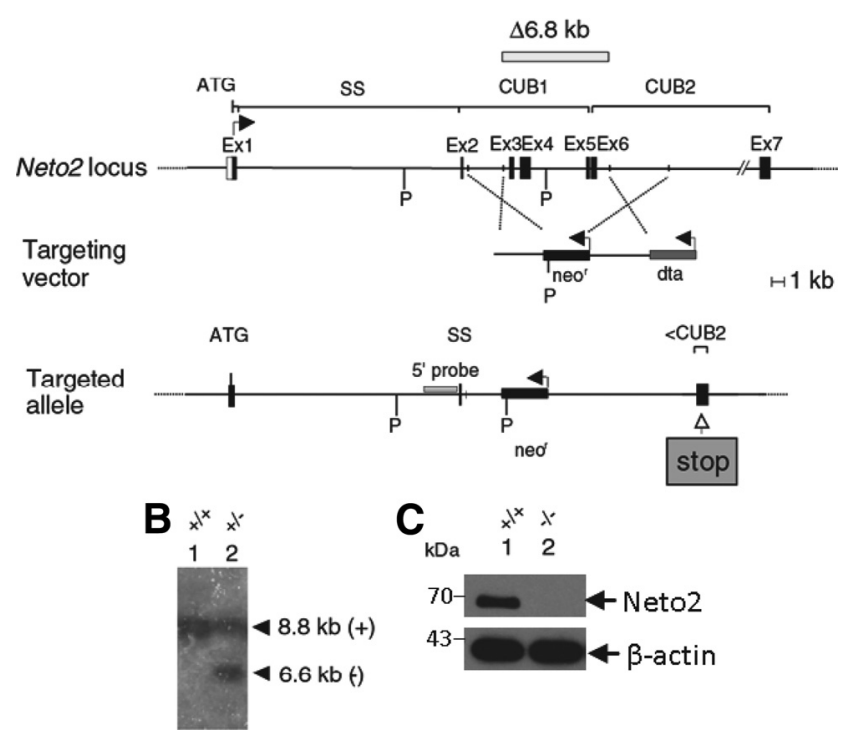

Figure 2. Generation of Neto2-null mice.Neto2 gene-targeting strategy. $A$, Top, A portion of the Neto2 gene showing exons (Ex). SS (signal sequence), CUB1, and (UB2 are encoded motifs; open box, noncoding sequences; solid boxes, coding sequences; P, Pstt restriction enzyme site. Middle, Neto2 targeting construct. neo ${ }^{r}$, Neomycin resistance gene; dta, Diphtheria toxin A gene-negative selection cassette. Bottom, Targeted Neto2 ${ }^{-1-}$ allele after homologous recombination. Arrows indicate the direction of transcription. The $5^{\prime}$ external probe is shown by a gray rectangle. $\boldsymbol{B}$, Genomic Southem blot from ES cell clones digested with Pst and hybridized with the $5^{\prime}$ probe. $C$, Immunoblot of brain lysates from Neto2 ${ }^{+/+}$, and Neto2-null mice using anti-Neto2 antibodies raised to the C-terminal 70 aa of Net02. The top arrowhead indicates the specific Neto2-immunoreactive band.

(Fig. $1 \mathrm{~A}$ ) in wild-type but not in Neto1-null mice. In contrast, we did not detect a coimmunoprecipitation of Netol and the AMPA receptor subunits GluA2/3 (Fig. $1 A$ ). To examine the roles of Neto2 in the brain, we generated Neto2-null mice (Fig. 2). The brains of these animals were normal in overall appearance, with no gross morphological abnormalities. We found that anti-Neto2 antibodies coimmunoprecipitated the GluK2 KAR subunit from wild-type but not Neto2-null mice (Fig. $1 B$ ). Reciprocally, the anti-GluK2 and anti-GluK5 antibodies coimmunoprecipitated both Neto1 and Neto2 from wild-type synaptosomes (Fig. 1C, lanes 2 and 3). Together, these results show, first, that Netol is unique among glutamate receptor-associated transmembrane proteins in that it can associate in vivo with two types of glutamate receptors (the NMDARs and the KARs), and second, that Neto 1 and Neto 2 are both bona fide interacting proteins of native KARs.

The PSD is an electron-dense structure in dendrites, where proteins directly involved in the regulation of synaptic function are organized and concentrated. Given that Neto1, Neto2, and KARs are all present at the PSD (Ng et al., 2009; Zhang et al., 2009), we next asked whether Neto 1 and Neto 2 were components of the PSD KAR protein complex. Both anti-Neto1 and anti Neto2 antibodies coimmunoprecipitated the GluK2 and GluK5 subunits of KARs, but did not coimmunoprecipitate the AMPA receptor subunits GluA2/3 from whole-brain PSD fractions (Fig. $1 E, F)$. Collectively, these findings indicate that both Netol and Neto2 associate with KARs but not with the AMPA-type glutamate receptors in the PSD.

Neto1 and Neto2 associate with GluK2 KARs predominantly through the second CUB domain

Both Neto1 and Neto2, have two extracellular CUB domains, a low-density lipoprotein receptor domain class A (LDLa) domain, a transmembrane domain, and a cytoplasmic domain. To define the region of Neto1 and Neto2 that mediates their interactions with KARs, we examined the binding of the GluK2-containing KARs to a series of Neto1 and Neto2 deletion proteins in HEK293 cells. Neto1 and Neto2 variants lacking the entire cytoplasmic domain were still able to coimmunoprecipitate with GluK2 (Fig. $3 B, D)$, suggesting that this domain is not critical for binding to KARs. Removal of the first CUB domain also failed to abolish Neto1:GluK2 or Neto2:GluK2 interactions (Fig. 3A, lane 3, C, lane 5), whereas deletion of the second CUB domain of Netol or Neto2 significantly reduced the amount of GluK2 that was coimmunoprecipitated, relative to the full-length Neto proteins $(33 \pm$ $10 \%$ of full-length Neto $2, p<0.01 ; 39 \pm 6 \%$ of full-length Neto 1 , $p<0.01$; mean \pm SEM) (Fig. $3 A$, lane $4, C$, lane 3 ). Furthermore, no interaction with GluK2 was observed when both extracellular CUB domains of Neto 1 were deleted (Fig. 3A, lane 5). Zhang et al. (2009) previously reported that the LDLa domain of Neto2 was necessary for modulating the channel activity of GluK2-KARs based on the observation that a mutant Neto2, in which two cysteine residues in the LDLa domain were changed to serines, failed to enhance glutamate-evoked KAR currents. To test whether the LDLa domain of Neto2 is required for binding to GluK2, we generated a Neto2 construct lacking the LDLa sequence. We found that the absence of the LDLa domain did not diminish the interaction between Neto2 and GluK2 (Fig. 3C, lane 4 ), indicating that while the LDLa domain of Neto2 may be required for modulation of GluK2 channel function, it is not necessary for Neto2 to interact with GluK2 homomeric receptors. Together, our results demonstrate that Neto 1 and Neto 2 bind to KARs through their extracellular CUB domains, and that this interaction is mediated primarily by the second CUB domain of each Neto protein.

\section{Reduced synaptic KAR currents in Neto1-null, but not Neto2-null mice}

Having established that both Netol and Neto2 are interacting proteins for KARs at PSDs, we next examined whether Netol or Neto 2 regulates native KAR function. Based on the strong expression of Neto1 and Neto2 in the CA3 region of the hippocampus (Michishita et al., 2003, 2004; Ng et al., 2009) and the well characterized contribution of postsynaptic KARs to MF-CA3 synapses (Castillo et al., 1997; Vignes and Collingridge, 1997; Mulle et al., 1998; Marchal and Mulle, 2004), we examined KARmediated EPSCs at MF-CA3 connections in acute hippocampal slices from wild-type and Neto knock-out mice. Consistent with previous in situ localization data (Michishita et al., 2003, 2004; Ng et al., 2009) (Allen Brain Atlas, http://www.brain-map.org/) and a potential role in regulating MF-CA3 synapses, we observed intense Netol and Neto 2 immunostaining within the stratum lucidum layer of wild-type mice (Fig. 4A). This result suggests a postsynaptic localization of these two proteins to proximal dendrites of CA3 pyramidal neurons and/or a presynaptic localization to the terminals of mossy fiber axons. However, given the enrichment of Neto 1 and Neto 2 in PSDs (Ng et al., 2009; Zhang et al., 2009) and their much stronger in situ profile in CA3 pyramidal cells over DG granule neurons (Michishita et al., 2003, 2004; $\mathrm{Ng}$ et al., 2009), it is likely that the signal we observed for Neto 1 and Neto2 in the stratum lucidum is predominantly postsynaptic.

To reliably evoke KAR-mediated events in CA3 pyramidal neurons, we used brief trains (four pulses at $20 \mathrm{~Hz}$ ) of MF stimulation and measured the amplitudes of EPSCs associated with the fourth pulse (Castillo et al., 1997; Vignes and Collingridge, 1997; Marchal and Mulle, 2004). We initially obtained an MF 


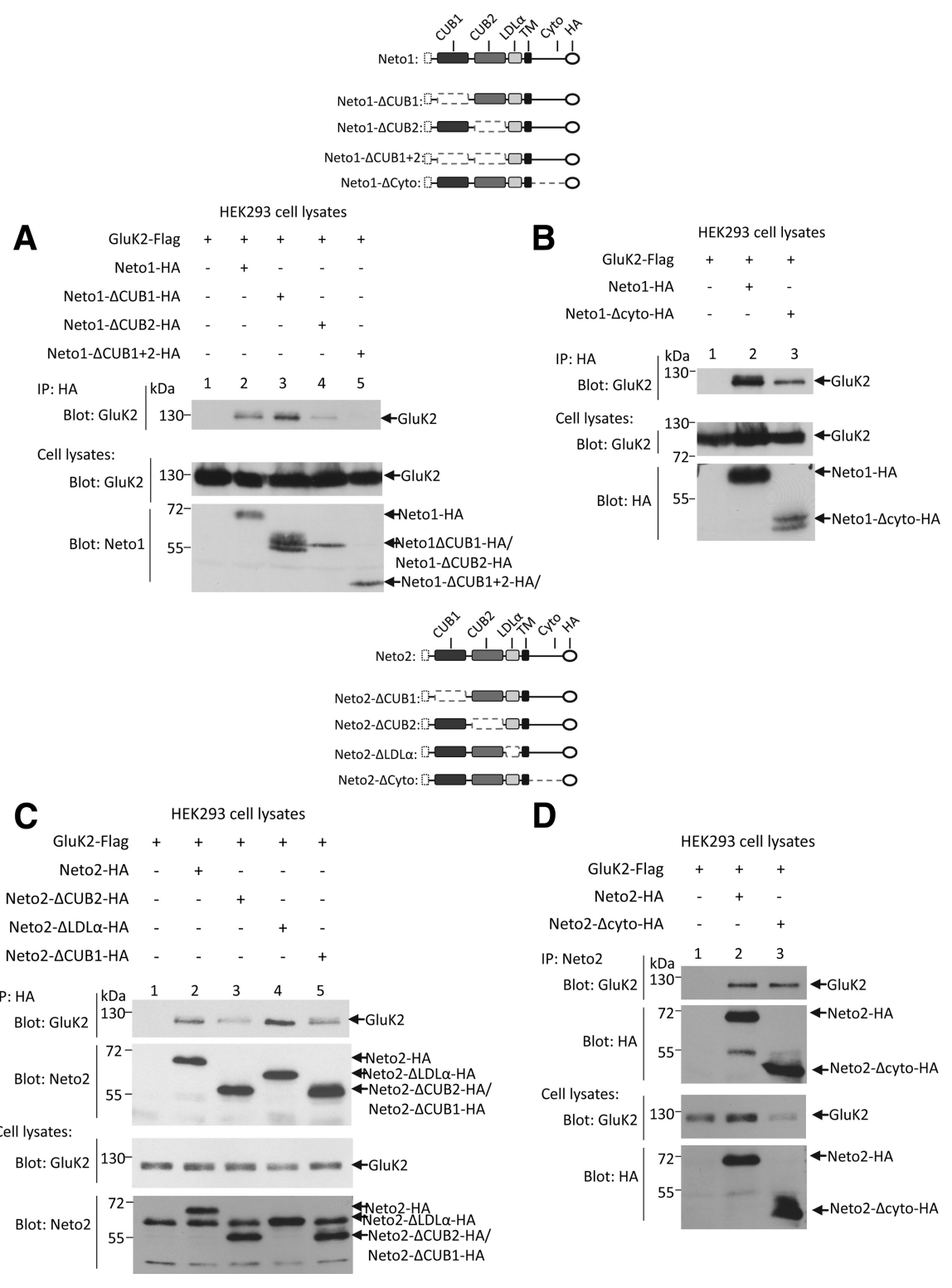

Figure 3. Neto1 and Net02 bind to GluK2 KARs through the extracellular CUB domains. $\boldsymbol{A}-\boldsymbol{D}$, Immunoblot of immunoprecipitates from transfected HEK293 cell lysates. The identities of the transfected CDNAs are indicated above each lane. Blot, Antibody used for immunoblot analysis; IP, antibody used for immunoprecipitation; HA, hemagglutinin tag. In the diagram of deletion proteins, the dashed-line boxes represent the domain that has been deleted from the full-length protein. $\boldsymbol{A}, \boldsymbol{B}$, The anti-Net01 antibody used for immunoblotting in $\boldsymbol{A}$ is raised against the C-terminal cytoplasmic domain of Net01. C, $\boldsymbol{D}$, The anti-Neto2 antibody used for immunoblotting in $\boldsymbol{C}$ is raised against the C-terminal 70 aa of Net02. The anti-Neto2 antibody used for immunoprecipitation in $\boldsymbol{D}$ is raised against the extracellular domain of Neto2. Similar results were observed in each of three experiments.

input by monitoring the combined AMPAR-and KAR-mediated EPSC while holding the postsynaptic pyramidal cell at $\mathrm{V}_{\mathrm{h}}=-70$ $\mathrm{mV}$, then applied GYKI $53655(50 \mu \mathrm{M})$ to pharmacologically isolate KAR-mediated events (Fig. 4B). This approach allowed us to control for slice-to-slice variability in MF recruitment by normalizing the KAR-mediated response to that of the initially observed AMPAR-dominated EPSC in the same recording before GYKI 53655 treatment. In mice lacking Neto1, we observed a severe deficit in KAR-mediated EPSCs compared with interleaved recordings from age-matched wild-type mice: KA/ AMPA EPSC amplitude ratios for wild-type and Neto1-null mice were $0.065 \pm 0.006$ and $0.040 \pm 0.005$, respectively (mean $\pm S D$, $p<0.01$ ) (Fig. 4C). Moreover, KAR-mediated EPSCs in Neto1- null mice displayed significantly faster decay kinetics compared with wild-type mice $(20 \pm 1.8$ and $50 \pm 4.9 \mathrm{~ms}$, respectively, for Neto1-null and wild-type mice; mean $\pm \mathrm{SD}, p<0.001$ ) (Fig. $4 D$ ), consistent with observations in heterologous expression systems where association with Neto2 has been shown to prolong the decay time constant of recombinant KARs (Zhang et al., 2009). Surprisingly, despite the ability of Neto2 to regulate recombinant KARs and its expression in the CA3 stratum lucidum (Fig. 4A), we found KAR-mediated transmission at MF-CA3 synapses in Neto2-null mice to be indistinguishable from that of wild-type mice (Fig. $4 B-D$ ), indicating that Neto2 is not required for normal KAR-mediated transmission at these synapses. Indeed, the combined loss of both Neto proteins in Neto1/ Neto2-double-null mice did not further exacerbate the phenotype observed in the Neto1-null mice (Fig. $4 B-D$ ).

Previously, we reported that Netolnull mice display a preferential reduction of synaptic GluN2A subunits and impaired NMDAR-mediated EPSCs at Schaffer collateral CA1 synapses (Ng et al., 2009). To determine whether MF-CA3 synapses exhibit a similar deficit in NMDAR-mediated transmission, we also probed NMDARmediated events at the end of every recording by blocking AMPARs and KARs, then moving $\mathrm{V}_{\mathrm{h}}=+40 \mathrm{mV}$ (Fig. $4 B$ ). Surprisingly, all mice examined yielded similar NMDA/AMPA ratios (Fig. 4C). The comparable NMDA/AMPA ratios observed across all mice confirm that the altered KA/ AMPA EPSC ratios observed in Neto1-null, and Neto1/Neto2-double-null mice, result from impaired KAR-mediated transmission rather than enhanced AMPAR function. However, the lack of effect on MF-CA3 NMDA/AMPA ratio was unexpected and prompted us to investigate whether loss of Netol affects NMDAR-mediated EPSCs at A/C CA3 synapses, which more closely resemble Schaffer collateral-CA1 pyramidal cell synapses. Consistent with our prior observations in CA1 (Ng et al., 2009), A/CCA3 pyramidal cell synapses exhibited reduced NMDA/AMPA EPSC ratios in Neto1-null neurons (Fig. 5A,B). Importantly, in additional interleaved control MF-CA3 recordings we again failed to observe any effect of Neto1 on NMDA/AMPA ratios (Fig. 5A,B), confirming that Netol regulation of postsynaptic receptor function is synapse specific.

Finally, we additionally assessed short-term frequency facilitation at MF-CA3 synapses by determining the ratio of the last to first AMPAR-mediated EPSCs and found that it was not significantly different across all animals, suggesting normal presynaptic function in all Neto-null mice (Figs. 4E, 5C). This result is surprising given the extensive literature describing presynaptic KAR-mediated regulation of glutamate release at MF-CA3 pyra- 

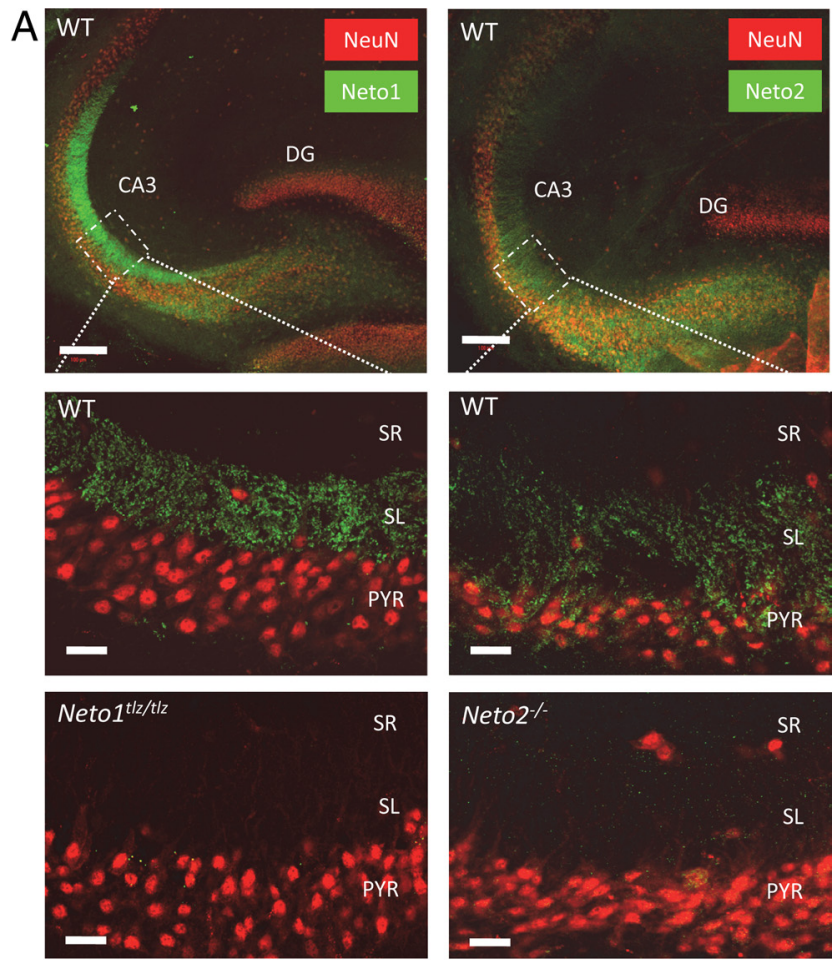

B Control wild type
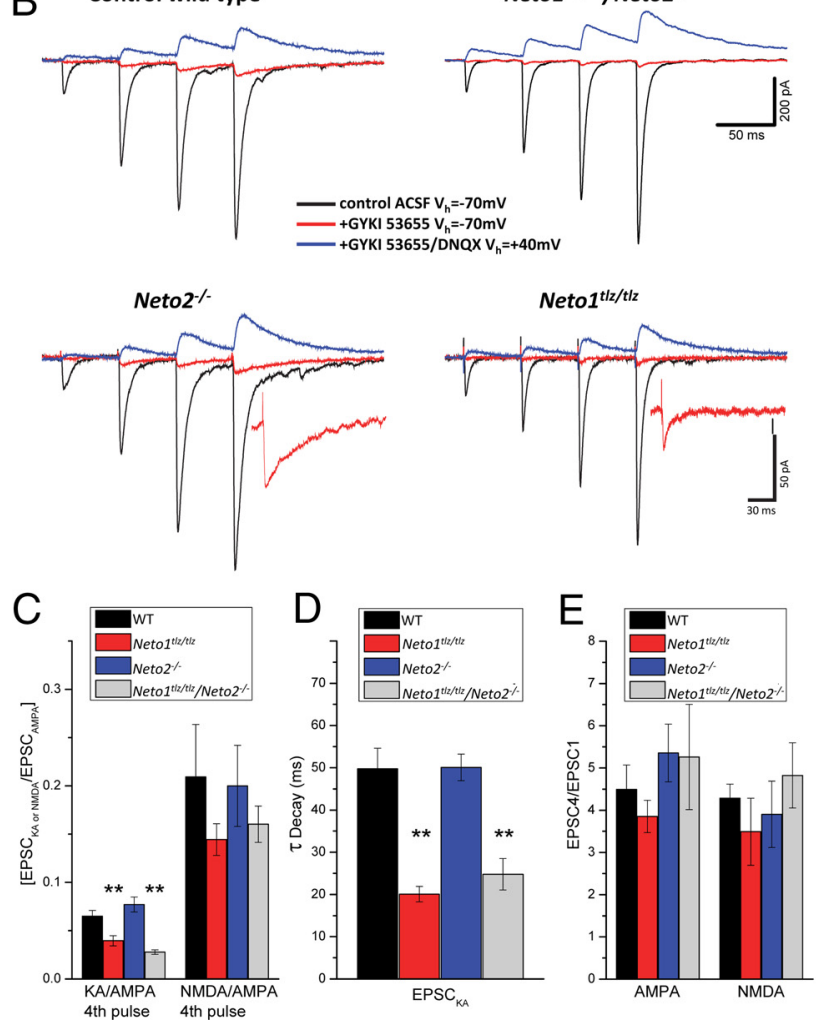

Figure 4. KAR-mediated EPSCs are reduced at hippocampal mossy fiber-CA3 pyramidal cell synapses in Net01-null, but not in Net02-null, mice. $\boldsymbol{A}$, Confocal micrographs of immunostained hippocampal slices showing the CA 3 and dentate gyrus region. Antibodies used are indicated in each box. Pyr, Pyramidal cell layer; SL, stratum lucidum; SR, stratum radiatum. Scale bars: top two panels, $100 \mu \mathrm{m}$; lower four panels, $20 \mu \mathrm{m}$. B, Representative traces of AMPAR, NMDAR, and KAR MF-CA3 EPSCs from individual wild-type (left), Net01-null (Neto $7^{\text {tlz/tlz }}$, lower right), Neto2-null (Neto2 ${ }^{-1-}$, lower left), or Net01/Net02-null (Neto $1^{\text {tlz/tlz }} /$ Neto2 ${ }^{-1-}$, right) CA3 pyramidal neurons. Initially, the dual AMPAR/KAR-mediated synaptic responses (bottom two traces) were monitored at a $V_{h}$ of $-70 \mathrm{mV}$, then the KAR-mediated component was pharmacologically

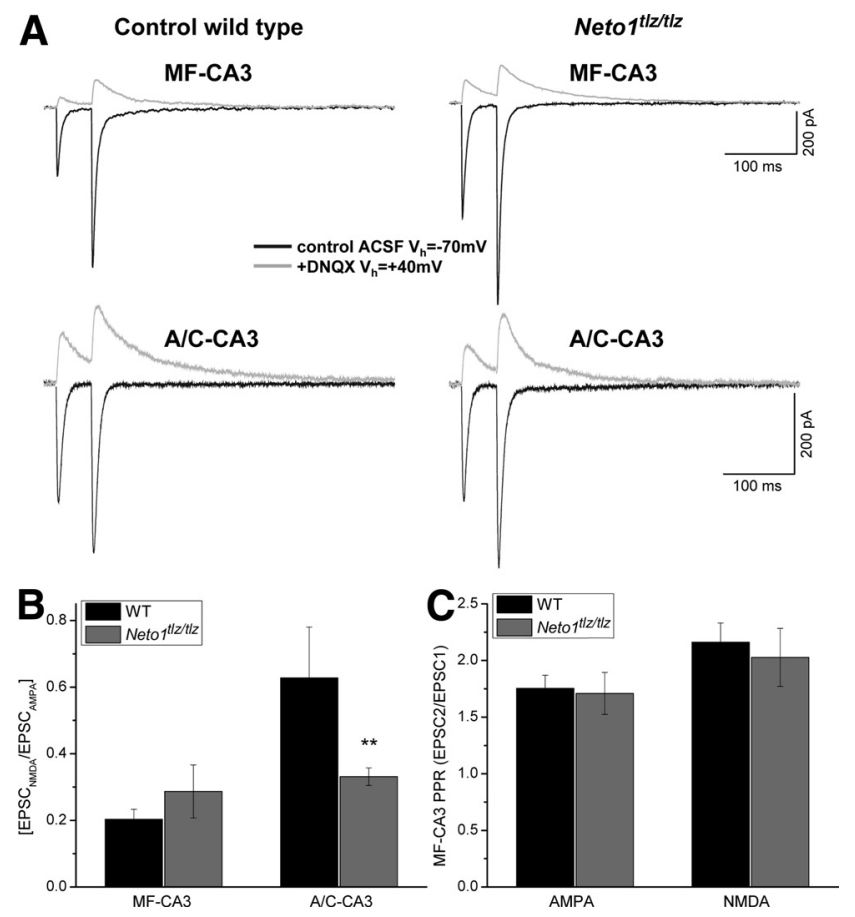

Figure 5. Reduced NMDAR-mediated transmission at A/C-CA3 synapses. $\boldsymbol{A}$, Representative traces of AMPAR-, and NMDAR-mediated EPSCs from individual wild-type (left) and Neto1-null (right) CA3 pyramidal cell recordings evoked by stimulating $M F$ (top) or $A / C$ (bottom) inputs. $\boldsymbol{B}$, C, Histograms summarizing data for EPSC $_{\mathrm{NMDA}} /$ EPSC $_{\mathrm{AMPA}}$ ratios for wild-type or Net01-null mice at MF-CA3 and A/C-CA3 synapses $(\boldsymbol{B})$, and ratios of second to first AMPAR or NMDAR-mediated EPSCs (P2/P1) for wild-type or Neto1-null mice at MF-CA3 synapses ( $C$ ( $n=9$ and 6 for MF-CA3 synapses in wild-type and Net01-null mice respectively; $n=12$ and 12 for $A / C-C A 3$ synapses in wild-type and Net01-null mice, respectively).

midal cell synapses (Contractor et al., 2000, 2001; Lauri et al., 2001; Schmitz et al., 2001). However, when we examined shortterm frequency facilitation using the NMDA component of transmission, we found that there was no difference with that observed using the AMPAR-mediated events (Figs. 4E, 5C). Given that AMPAR-mediated EPSCs were recorded with KAR transmission intact while NMDAR-mediated events were recorded with KARs blocked, the results indicate that presynaptic KARs did not participate in regulating transmission under our experimental conditions (Kwon and Castillo, 2008a). Indeed, presynaptic KAR-mediated regulation of MF-CA3 transmission during paired or four-pulse protocols likely requires shorter interpulse intervals (Contractor et al., 2001; Marchal and Mulle, 2004). Altogether, our findings indicate that the reduced KA/ AMPA EPSC ratios we observed in Neto1-null and Neto1/Neto2double-null mice reflect a selective deficit in postsynaptic KAR activation due to the absence of Netol.

isolated by applying the AMPAR-specific antagonist GYKI 53655. The GYKI-resistant component at $V_{h}=-70 \mathrm{mV}$ was confirmed to be KAR mediated by subsequent application of DNQX in the continued presence of GYKI 53655. The holding potential is then moved to $+40 \mathrm{mV}$ to obtain the NMDAR-mediated component of EPSCs (top trace). Insets for the Net01-null and Neto2-null sets of traces display the fourth KAR-mediated event at higher gain. $\boldsymbol{C}-\boldsymbol{E}$, Histograms summarizing group data for EPSC $_{\mathrm{KA}} / \mathrm{EPSC}_{\mathrm{AMPA}}$, and $\mathrm{EPSC}_{\mathrm{NMDA}} / \mathrm{EPSC}_{\mathrm{AMPA}}$ ratios $(\boldsymbol{C})$, mean $\mathrm{EPSC}_{\mathrm{KA}}$ decay time constants $(\boldsymbol{D})$, and ratios of fourth and first AMPAR- or NMDAR-mediated EPSCS (P4/P1) $(\boldsymbol{E})$, for wild-type $(n=10)$, Net01-null $(n=14)$, Net02-null $(n=12)$, and Neto1/Neto2double-null $(n=12)$ neurons. ${ }^{* *} p<0.01$. 
A Hippocampal Hippocampal homogenates PSDs

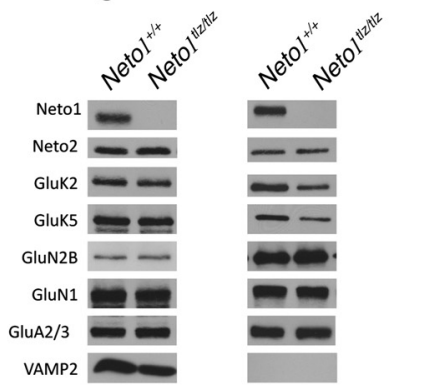

\section{B}



C Hippocampal Hippocampal homogenates PSDs


E Hippocampal Hippocampal
homogenates PSDs

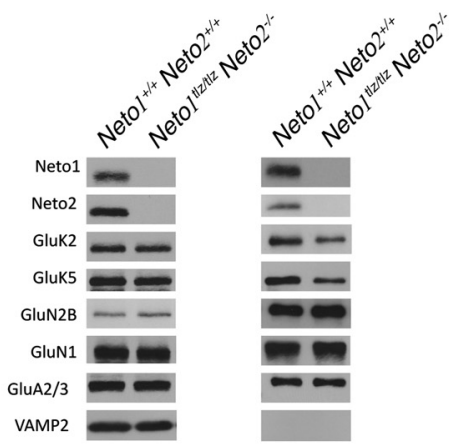



Figure 6. KAR subunits are reduced in the hippocampal PSD of Net01-null mice. $\boldsymbol{A}-\boldsymbol{E}$, Immunoblots and histogram of synaptic proteins from whole hippocampal homogenates and hippocampal PSD fractions from $+/+$ and Neto1-null $\left(\right.$ Neto $\left.1^{\text {tlz/tzz }}\right)$ mice $(\boldsymbol{A}$, $\boldsymbol{B}) ;+/+$ and Net02-null (Neto2 ${ }^{-/-}$) mice $(\boldsymbol{C}, \boldsymbol{D})$; and $+/+$ and Net01/Net02-null (Neto $1^{\text {ttz/tzz }}$ Neto2 ${ }^{-/-}$) mice $(\boldsymbol{E}, \boldsymbol{F})$. Antibodies used for detection are indicated on the left. Blots shown are representative of three experiments. Histogram shows normalized levels of different synaptic proteins in null-mice hippocampal homogenate relative to that of $+/+$ (white bars), and in null-mice hippocampal PSD relative to that of $+/+$ (black bars). ${ }^{* *} p<0.01$, paired $t$ test, $n=3$.

type mice (Fig. 6A, $C$ ). The abundance of other synaptic proteins, such as GluN1, GluN2B, and GluA2/3, was comparable in PSDs from Neto1-null and wild-type mice and Neto1/Neto2-double-null and wildtype mice (Fig. 6A,C). On the other hand, the abundance of all synaptic proteins examined, including Neto1, was not significantly different between Neto2-null and wild-type mice (Fig. 6B). These results are consistent with the observed reduction of KAR-mediated synaptic transmission in the Neto1-null and in the Neto1/Neto2-null mice, and with the normal synaptic function of KARs in the Neto2-null mice. We, therefore, conclude that Neto1, but not Neto2, serves as a critical regulatory element of native, postsynaptic KAR complexes at hippocampal PSDs.

\section{Discussion}

In this report, we investigated the role of Netol as a regulatory protein of KARs in vivo. We established that in the brain Neto1 is a critical auxiliary subunit of the KAR protein complex. We discovered that although both Neto 1 and Neto 2 are associated with KARs in synaptosomal and PSD fractions, and that both Neto proteins interacted with GluK2-containing KARs through their extracellular CUB domains, only the loss of Netol reduced the abundance of KAR subunits at hippocampal PSDs. Consistent with this finding, we identified a substantial $(\sim 50 \%)$ reduction in KAR-mediated EPSCs at hippocampal MF-CA3 synapses in Neto1-null mice. Moreover, KAR-mediated EPSCs in mice lacking Neto1 displayed significantly faster decay kinetics compared with wild-type mice. Collectively, these findings indicate that Netol plays a crucial role in regulating postsynaptic KARs at MF-CA3 synapses.

KARs are tetrameric glutamate receptors that can be found either as functional homomeric GluK1, GluK2, or GluK3 receptors, each with unique physiology and pharmacology (Hollmann and Heinemann, 1994; Schiffer et al., 1997; Dingledine et al., 1999), or as heteromeric

Neto1, but not Neto2, is required for the synaptic abundance of KARs

The reduction in KAR-mediated EPSCs at hippocampal MF-CA3 synapses in Neto1-null mice suggests that the loss of Netol leads to a decrease in the number and/or the function of synaptic KARs. To determine whether the absence of Neto1 was associated with any change in the abundance of synaptic KARs, we prepared hippocampal PSDs from Neto1-null and Neto1/Neto2-doublenull mice. We found an $\sim 40-50 \%$ decrease in the levels of GluK2 and GluK5 KAR subunits at PSDs in both Neto1-null (47 $\pm 9 \%$ and $57 \pm 7 \%$ of wild-type mice, respectively, for GluK2 and GluK5; mean \pm SD, $p<0.001)$, and Neto1/Neto2-double-null mice ( $42 \pm 5 \%$ and $50 \pm 15 \%$ of wild-type mice, respectively, for GluK2 and GluK5; mean \pm SD, $p<0.001$ ), compared with wildreceptors from the combination of GluK4-5 with GluK1-3 (Werner et al., 1991; Herb et al., 1992). A number of proteins have been recently implicated in the cellular trafficking, synaptic localization, and modulation of the channel properties of KARs (Garcia et al., 1998; Mehta et al., 2001; Coussen et al., 2002; Bowie et al., 2003; Hirbec et al., 2003; Coussen et al., 2005; Laezza et al., 2007; Zhang et al., 2009). Among these KAR-interacting proteins, Neto 2 has been shown to prolong the decay kinetics of recombinant, homomeric GluK2 KARs (Zhang et al., 2009). It is not known, however, whether Neto2 or its homolog Neto1 have a similar effect on heteromeric kainate receptors such as GluK2/ GluK5, which have different biophysical properties from the homomeric ion channels (Herb et al., 1992). At mossy fiber syn- 
apses, we have observed a reduction in the decay time constant for native KARs in the absence of Netol. This result suggests that Neto1 may be regulating the decay kinetics of synaptic KARs, in a way similar to the role of Neto 2 on the recombinant GluK2 receptors. On the other hand, recent studies have shown that the GluK5 subunit confers the slower decay kinetics of KARs at mossy fiber synapses (Contractor et al., 2003), and of GluK2/ GluK5 heteromers in heterologous cells (Barberis et al., 2008). Therefore, given the role of Netol in regulating the abundance of kainate receptor subunits in the PSD, it is also possible that the faster kinetics of the KARs in the Neto1-null neurons are due at least in part to a loss of synaptic GluK5-containing KARs.

The role of Netol in regulating KARs may be akin to the function of the transmembrane AMPA receptor regulatory proteins (TARPs), which modulate the synaptic localization and the channel properties of AMPA receptors (Tomita, 2010). Interestingly, despite the fact that the CUB domain protein SOL-1 regulates the GLR-1 AMPA receptors in the invertebrate Caenorhabditis elegans (Zheng et al., 2004, 2006), neither Neto1 nor Neto2 interacts with vertebrate AMPA receptors. Conversely, TARPs are not associated with KARs or NMDARs (Chen et al., 2000; Zhang et al., 2009). These differences between vertebrate and invertebrate AMPA receptor accessory proteins suggest that different mechanisms may have evolved for regulating the function of this ion channel, or that there are yet to be identified CUB domain-containing proteins that regulate the vertebrate AMPA receptors.

We previously identified Netol as an NMDAR-associated protein (Ng et al., 2009). Neto1-null mice displayed a preferential reduction of synaptic GluN2A subunits and impaired NMDARmediated EPSCs at Schaffer collateral-CA1 synapses. Moreover, at these synapses where long-term potentiation (LTP) is NMDAR dependent, loss of Netol reduced the magnitude of the potentiation to $\sim 50 \%$ of wild-type mice. NMDAR-dependent learning and memory, as measured by Morris water maze tests, was also disrupted in Neto1-null mice. These results indicated that Neto1 is an important subunit of the NMDAR complex required for NMDAR-mediated synaptic plasticity and learning. In the present study, we found that loss of Netol led to a significant reduction of NMDAR-mediated EPSCs at A/C collateral synapses of the CA3, a result that is consistent with our previous observations. At MF-CA3 synapses, however, we found that KARmediated, but not NMDAR-mediated, synaptic currents were altered in Neto1-null neurons. These results suggest that the accessory proteins required for functional regulation of a particular glutamate receptor may differ among synapses, even within a single type of neuron.

The differential Netol effect on NMDARs at A/C versus MF synapses is reflective of the known structural and functional differences between these two synapses (Zalutsky and Nicoll, 1990; Williams and Johnston, 1991; Ishizuka et al., 1995; Salin et al., 1996). For example, LTP induction at A/C-CA3 synapses, as well as at Schaffer collateral-CA1 and perforant path synapses in the DG, is dependent on NMDAR activation that results in a postsynaptic enhancement of AMPAR neurotransmission (Bliss and Collingridge, 1993). MF-CA3 synapses, on the other hand, express lower levels of NMDARs (Watanabe et al., 1998) and display a presynaptic, NMDAR-independent form of LTP (Nicoll and Schmitz, 2005). Furthermore, MF-CA3 synapses, but not A/C-CA3 synapses, selectively express a depolarization-induced form of LTD that is dependent on postsynaptic $\mathrm{Ca}^{2+}$ elevation (Lei et al., 2003), as well as a type of LTP characterized by a long-lasting increase in NMDAR-mediated transmission (Kwon and Castillo, 2008b; Rebola et al., 2008).
Differences in the functional properties of MF versus A/CCA3 synapses are likely a result of the differential trafficking and stabilization of proteins at these two synapses. For instance, AMPARs display an even distribution among all MF synapses, but are absent in a large number of $\mathrm{A} / \mathrm{C}$ and $\mathrm{CA} 1$ synapses (Nusser et al., 1998) where they can be incorporated into the postsynaptic membrane during the expression of LTP (Shi et al., 2001; Kakegawa et al., 2004). In addition, postsynaptic KARs also show synapse-specific targeting within a single neuron as KAR-mediated EPSCs have only been observed at MF, but not at AC-CA3 synapses (Castillo et al., 1997; Vignes and Collingridge, 1997). While a number of molecular and functional differences have been described for the MF-CA3 and the A/C-CA3 synapses, similar characteristics have been observed between the A/C-CA3 synapses and those of CA3 terminals onto CA1 neurons. Hence, our findings of the differential dependence of NMDAR EPSCs on Neto1 at MF-CA3 versus A/C-CA3 are consistent with the general characteristics of these synapses. It will be interesting, for future studies, to explore whether this differential Netol effect on NMDARs results from KARs titrating Netol away from the NMDARs in synapses where both ion channels are expressed. Altogether, our results show that Netol can be an auxiliary protein for either the NMDA or the kainate class of glutamate receptors, depending on the synapse or the brain region. Thus, our findings suggest the concept that a specific auxiliary protein, namely Neto1, may regulate more than one type of ligand-gated ion channel.

Other CUB domain-containing proteins that associate with ligand-gated ion channels are the C. elegans proteins SOL-1 (Zheng et al., 2004, 2006) and LEV-10 (Gally et al., 2004), which are part of the GLR-1 AMPA receptors and the acetylcholine receptors, respectively. SOL-1 modulates the gating of GLR-1 ionotropic receptors, whereas LEV-10 controls the synaptic localization of the acetylcholine receptors. In vertebrates, we have shown that Netol is an NMDAR-interacting protein that regulates the synaptic abundance of the GluN2A subunit ( $\mathrm{Ng}$ et al., 2009), and here we report the in vivo association of both Netol and Neto 2 with the kainate class of glutamate receptors. Collectively, our findings support the hypothesis that there is an evolutionarily conserved role for CUB domain proteins as regulatory subunits of ion channels ( $\mathrm{Ng}$ et al., 2009), and suggest that additional CUB domain proteins may be important accessory proteins for other ligand-gated ion channels.

A previous study has proposed that Neto2 acts as a KAR auxiliary subunit that modulates the kinetics of recombinant KARs in heterologous cells and KARs in cultured cerebellar granule neurons (Zhang et al., 2009). Our present results show, however, that at hippocampal MF-CA3 synapses, loss of Neto2 does not affect KAR-mediated EPSCs or decay kinetics, even though Neto 2 is expressed in stratum lucidum in wild-type animals. One possible explanation for this apparent discrepancy may be differences in the properties of recombinant GluK2 homomeric receptors used in the previous study (Zhang et al., 2009) versus the native KARs examined in our work. Another significant difference between our findings and those of Zhang et al. (2009) is the context in which the effect of Neto 2 on KARs was investigated. In our study, we examined the impact of the loss of Neto 2 on KARs in vivo rather than the effect of Neto 2 overexpression on recombinant GluK2-KARs in heterologous cells or cultured neurons. Both Neto1 and Neto2 are expressed in the stratum lucidum layer where mossy fibers synapse with CA3 pyramidal cells, so a third possible explanation for the normal KAR function in the Neto2null mice could be the predominant role of Netol on KAR regu- 
lation in cells where both proteins are expressed. Future studies should, therefore, investigate whether lack of Neto2 affects KARs in brain regions where Neto2, but not Neto1, and KARs are highly expressed (Petralia et al., 1994; Michishita et al., 2004).

In summary, we have discovered that Netol is a key component of KAR protein complexes. At MF-CA3 synapses, KAR synaptic transmission is decreased in Neto1-null mice, likely as a result of the reduction of KAR protein levels at the PSD. In addition, in mice lacking Neto1, we observed a faster decay of KARmediated EPSCs. Altogether, our findings indicate that Netol is a critical auxiliary subunit of native, synaptic KARs.

\section{References}

Barberis A, Sachidhanandam S, Mulle C (2008) GluR6/KA2 kainate receptors mediate slow-deactivating currents. J Neurosci 28:6402-6406.

Bliss TV, Collingridge GL (1993) A synaptic model of memory: long-term potentiation in the hippocampus. Nature 361:31-39.

Bowie D, Garcia EP, Marshall J, Traynelis SF, Lange GD (2003) Allosteric regulation and spatial distribution of kainate receptors bound to ancillary proteins. J Physiol 547:373-385.

Bureau I, Bischoff S, Heinemann SF, Mulle C (1999) Kainate receptormediated responses in the CA1 field of wild-type and GluR6-deficient mice. J Neurosci 19:653-663.

Castillo PE, Malenka RC, Nicoll RA (1997) Kainate receptors mediate a slow postsynaptic current in hippocampal CA3 neurons. Nature 388:182-186.

Chen L, Chetkovich DM, Petralia RS, Sweeney NT, Kawasaki Y, Wenthold RJ, Bredt DS, Nicoll RA (2000) Stargazin regulates synaptic targeting of AMPA receptors by two distinct mechanisms. Nature 408:936-943.

Cho KO, Hunt CA, Kennedy MB (1992) The rat brain postsynaptic density fraction contains a homolog of the Drosophila discs-large tumor suppressor protein. Neuron 9:929-942.

Chow RL, Volgyi B, Szilard RK, Ng D, McKerlie C, Bloomfield SA, Birch DG, McInnes RR (2004) Control of late off-center cone bipolar cell differentiation and visual signaling by the homeobox gene Vsx1. Proc Natl Acad Sci U S A 101:1754-1759.

Contractor A, Swanson GT, Sailer A, O'Gorman S, Heinemann SF (2000) Identification of the kainate receptor subunits underlying modulation of excitatory synaptic transmission in the CA3 region of the hippocampus. J Neurosci 20:8269-8278.

Contractor A, Swanson G, Heinemann SF (2001) Kainate receptors are involved in short- and long-term plasticity at mossy fiber synapses in the hippocampus. Neuron 29:209-216.

Contractor A, Sailer AW, Darstein M, Maron C, Xu J, Swanson GT, Heinemann SF (2003) Loss of kainate receptor-mediated heterosynaptic facilitation of mossy-fiber synapses in KA2 ${ }^{-1-}$ mice. J Neurosci 23:422-429.

Cossart R, Esclapez M, Hirsch JC, Bernard C, Ben-Ari Y (1998) GluR5 kainate receptor activation in interneurons increases tonic inhibition of pyramidal cells. Nat Neurosci 1:470-478.

Coussen F, Normand E, Marchal C, Costet P, Choquet D, Lambert M, Mège RM, Mulle C (2002) Recruitment of the kainate receptor subunit glutamate receptor 6 by cadherin/catenin complexes. J Neurosci 22:6426-6436.

Coussen F, Perrais D, Jaskolski F, Sachidhanandam S, Normand E, Bockaert J, Marin P, Mulle C (2005) Co-assembly of two GluR6 kainate receptor splice variants within a functional protein complex. Neuron 47:555-566.

Darstein M, Petralia RS, Swanson GT, Wenthold RJ, Heinemann SF (2003) Distribution of kainate receptor subunits at hippocampal mossy fiber synapses. J Neurosci 23:8013-8019.

Dingledine R, Borges K, Bowie D, Traynelis SF (1999) The glutamate receptor ion channels. Pharmacol Rev 51:7-61.

Egebjerg J, Bettler B, Hermans-Borgmeyer I, Heinemann S (1991) Cloning of a cDNA for a glutamate receptor subunit activated by kainate but not AMPA. Nature 351:745-748.

Fernandes HB, Catches JS, Petralia RS, Copits BA, Xu J, Russell TA, Swanson GT, Contractor A (2009) High-affinity kainate receptor subunits are necessary for ionotropic but not metabotropic signaling. Neuron 63:818-829.

Fisahn A, Heinemann SF, McBain CJ (2005) The kainate receptor subunit GluR6 mediates metabotropic regulation of the slow and medium AHP currents in mouse hippocampal neurones. J Physiol 562:199-203.
Frerking M, Malenka RC, Nicoll RA (1998) Synaptic activation of kainate receptors on hippocampal interneurons. Nat Neurosci 1:479-486.

Gally C, Eimer S, Richmond JE, Bessereau JL (2004) A transmembrane protein required for acetylcholine receptor clustering in Caenorhabditis elegans. Nature 431:578-582.

Garcia EP, Mehta S, Blair LA, Wells DG, Shang J, Fukushima T, Fallon JR, Garner CC, Marshall J (1998) SAP90 binds and clusters kainate receptors causing incomplete desensitization. Neuron 21:727-739.

Gingrich JR, Pelkey KA, Fam SR, Huang Y, Petralia RS, Wenthold RJ, Salter MW (2004) Unique domain anchoring of Src to synaptic NMDA receptors via the mitochondrial protein NADH dehydrogenase subunit 2. Proc Natl Acad Sci U S A 101:6237-6242.

Herb A, Burnashev N, Werner P, Sakmann B, Wisden W, Seeburg PH (1992) The KA-2 subunit of excitatory amino acid receptors shows widespread expression in brain and forms ion channels with distantly related subunits. Neuron 8:775-785.

Hirbec H, Francis JC, Lauri SE, Braithwaite SP, Coussen F, Mulle C, Dev KK, Coutinho V, Meyer G, Isaac JT, Collingridge GL, Henley JM, Couthino V (2003) Rapid and differential regulation of AMPA and kainate receptors at hippocampal mossy fibre synapses by PICK1 and GRIP. Neuron 37:625-638.

Hollmann M, Heinemann S (1994) Cloned glutamate receptors. Annu Rev Neurosci 17:31-108.

Ishizuka N, Cowan WM, Amaral DG (1995) A quantitative analysis of the dendritic organization of pyramidal cells in the rat hippocampus. J Comp Neurol 362:17-45.

Kakegawa W, Tsuzuki K, Yoshida Y, Kameyama K, Ozawa S (2004) Inputand subunit-specific AMPA receptor trafficking underlying long-term potentiation at hippocampal CA3 synapses. Eur J Neurosci 20:101-110.

Kamiya H, Ozawa S (2000) Kainate receptor-mediated presynaptic inhibition at the mouse hippocampal mossy fibre synapse. J Physiol 523:653-665.

Kwon HB, Castillo PE (2008a) Role of glutamate autoreceptors at hippocampal mossy fiber synapses. Neuron 60:1082-1094.

Kwon HB, Castillo PE (2008b) Long-term potentiation selectively expressed by NMDA receptors at hippocampal mossy fiber synapses. Neuron $57: 108-120$.

Laezza F, Wilding TJ, Sequeira S, Coussen F, Zhang XZ, Hill-Robinson R, Mulle C, Huettner JE, Craig AM (2007) KRIP6: a novel BTB/kelch protein regulating function of kainate receptors. Mol Cell Neurosci 34:539-550.

Lauri SE, Bortolotto ZA, Bleakman D, Ornstein PL, Lodge D, Isaac JT, Collingridge GL (2001) A critical role of a facilitatory presynaptic kainate receptor in mossy fiber LTP. Neuron 32:697-709.

Lei S, Pelkey KA, Topolnik L, Congar P, Lacaille JC, McBain CJ (2003) Depolarization-induced long-term depression at hippocampal mossy fiber-CA3 pyramidal neuron synapses. J Neurosci 23:9786-9795.

Marchal C, Mulle C (2004) Postnatal maturation of mossy fibre excitatory transmission in mouse CA3 pyramidal cells: a potential role for kainate receptors. J Physiol 561:27-37.

Mehta S, Wu H, Garner CC, Marshall J (2001) Molecular mechanisms regulating the differential association of kainate receptor subunits with SAP90/PSD-95 and SAP97. J Biol Chem 276:16092-16099.

Melyan Z, Wheal HV, Lancaster B (2002) Metabotropic-mediated kainate receptor regulation of IsAHP and excitability in pyramidal cells. Neuron 34:107-114

Michishita M, Ikeda T, Nakashiba T, Ogawa M, Tashiro K, Honjo T, Doi K, Itohara S, Endo S (2003) A novel gene, Btcll, encoding CUB and LDLa domains is expressed in restricted areas of mouse brain. Biochem Biophys Res Commun 306:680-686.

Michishita M, Ikeda T, Nakashiba T, Ogawa M, Tashiro K, Honjo T, Doi K, Itohara S, Endo S (2004) Expression of Btcl2, a novel member of Btcl gene family, during development of the central nervous system. Brain Res Dev Brain Res 153:135-142.

Mulle C, Sailer A, Pérez-Otaño I, Dickinson-Anson H, Castillo PE, Bureau I, Maron C, Gage FH, Mann JR, Bettler B, Heinemann SF (1998) Altered synaptic physiology and reduced susceptibility to kainate-induced seizures in GluR6-deficient mice. Nature 392:601-605.

Ng D, Pitcher GM, Szilard RK, Sertié A, Kanisek M, Clapcote SJ, Lipina T, Kalia LV, Joo D, McKerlie C, Cortez M, Roder JC, Salter MW, McInnes RR (2009) Neto1 is a novel CUB-domain NMDA receptor-interacting protein required for synaptic plasticity and learning. PLoS Biol 7:e41. 
Nicoll RA, Schmitz D (2005) Synaptic plasticity at hippocampal mossy fibre synapses. Nat Rev Neurosci 6:863-876.

Nusser Z, Lujan R, Laube G, Roberts JD, Molnar E, Somogyi P (1998) Cell type and pathway dependence of synaptic AMPA receptor number and variability in the hippocampus. Neuron 21:545-559.

Pelkey KA, Lavezzari G, Racca C, Roche KW, McBain CJ (2005) mGluR7 is a metaplastic switch controlling bidirectional plasticity of feedforward inhibition. Neuron 46:89-102.

Petralia RS, Wang YX, Wenthold RJ (1994) Histological and ultrastructural localization of the kainate receptor subunits, KA2 and GluR6/7, in the rat nervous system using selective antipeptide antibodies. J Comp Neurol 349:85-110.

Rebola N, Lujan R, Cunha RA, Mulle C (2008) Adenosine A2A receptors are essential for long-term potentiation of NMDA-EPSCs at hippocampal mossy fiber synapses. Neuron 57:121-134.

Ruiz A, Sachidhanandam S, Utvik JK, Coussen F, Mulle C (2005) Distinct subunits in heteromeric kainate receptors mediate ionotropic and metabotropic function at hippocampal mossy fiber synapses. J Neurosci 25:11710-11718.

Salin PA, Scanziani M, Malenka RC, Nicoll RA (1996) Distinct short-term plasticity at two excitatory synapses in the hippocampus. Proc Natl Acad Sci U S A 93:13304-13309.

Schiffer HH, Swanson GT, Heinemann SF (1997) Rat GluR7 and a carboxyterminal splice variant, GluR7b, are functional kainate receptor subunits with a low sensitivity to glutamate. Neuron 19:1141-1146.

Schmitz D, Mellor J, Nicoll RA (2001) Presynaptic kainate receptor mediation of frequency facilitation at hippocampal mossy fiber synapses. Science 291:1972-1976.

Schneider Gasser EM, Straub CJ, Panzanelli P, Weinmann O, Sassoè-Pognetto M, Fritschy JM (2006) Immunofluorescence in brain sections: simultaneous detection of presynaptic and postsynaptic proteins in identified neurons. Nat Protoc 1:1887-1897.

Shi S, Hayashi Y, Esteban JA, Malinow R (2001) Subunit-specific rules governing AMPA receptor trafficking to synapses in hippocampal pyramidal neurons. Cell 105:331-343.
Sommer B, Burnashev N, Verdoorn TA, Keinänen K, Sakmann B, Seeburg PH (1992) A glutamate receptor channel with high affinity for domoate and kainate. ЕMBO J 11:1651-1656.

Tomita S (2010) Regulation of ionotropic glutamate receptors by their auxiliary subunits. Physiology (Bethesda) 25:41-49.

Traynelis SF, Wollmuth LP, McBain CJ, Menniti FS, Vance KM, Ogden KK, Hansen KB, Yuan H, Myers SJ, Dingledine R (2010) Glutamate receptor ion channels: structure, regulation, and function. Pharmacol Rev 62:405-496.

Vignes M, Collingridge GL (1997) The synaptic activation of kainate receptors. Nature 388:179-182.

Watanabe M, Fukaya M, Sakimura K, Manabe T, Mishina M, Inoue Y (1998) Selective scarcity of NMDA receptor channel subunits in the stratum lucidum (mossy fibre-recipient layer) of the mouse hippocampal CA3 subfield. Eur J Neurosci 10:478-487.

Werner P, Voigt M, Keinänen K, Wisden W, Seeburg PH (1991) Cloning of a putative high-affinity kainate receptor expressed predominantly in hippocampal CA3 cells. Nature 351:742-744.

Williams SH, Johnston D (1991) Kinetic properties of two anatomically distinct excitatory synapses in hippocampal CA3 pyramidal neurons. J Neurophysiol 66:1010-1020.

Zalutsky RA, Nicoll RA (1990) Comparison of two forms of long-term potentiation in single hippocampal neurons. Science 248:1619-1624.

Zhang W, St-Gelais F, Grabner CP, Trinidad JC, Sumioka A, MorimotoTomita M, Kim KS, Straub C, Burlingame AL, Howe JR, Tomita S (2009) A transmembrane accessory subunit that modulates kainate-type glutamate receptors. Neuron 61:385-396.

Zheng Y, Mellem JE, Brockie PJ, Madsen DM, Maricq AV (2004) SOL-1 is a CUB-domain protein required for GLR-1 glutamate receptor function in C. elegans. Nature 427:451-457.

Zheng Y, Brockie PJ, Mellem JE, Madsen DM, Walker CS, Francis MM, Maricq AV (2006) SOL-1 is an auxiliary subunit that modulates the gating of GLR-1 glutamate receptors in Caenorhabditis elegans. Proc Natl Acad Sci U S A 103:1100-1105. 